\title{
Psychometric properties and validation of the Polish adaptation of the Light Triad Scale
}

\author{
Rafat Gerymski (D) A,B,C,D,E,F, Dariusz Krok (D) A,D,E,F \\ Department of Health Psychology and Quality of Life, Institute of Psychology, Opole University, Opole, Poland
}

BACKGROUND

The aim of the study was to examine the development and structural validation of the Polish version of the Light Triad Scale, which measures three factors: Faith in Humanity, Humanism, and Kantianism. This tool reflects caring and beneficent orientation toward other people, which is demonstrated in everyday behaviour.

\section{PARTICIPANTS AND PROCEDURE}

The participants included 400 people aged between 18 and $80(M=29.17, S D=10.60)$. To measure psychometric properties and for validation of the scale, we used the Polish Dirty Dozen scale and International Personality Item PoolBig Five Aspect Scales.

\section{RESULTS}

Confirmatory factor analysis, reliability analysis using $\alpha$ and $\omega$ coefficients, and two measures of validity (content and criterion validity) were applied. The statistical analy- ses confirmed an acceptable fit of the three-factor model. The $\alpha$ and $\omega$ reliability coefficients were satisfactory, with the highest value for Faith in Humanity, and the lowest one for Kantianism. The validity indices of CVR and CVI indicated that the Polish scale items fit well into the concept of the Light Triad.

CONCLUSIONS

Overall, the Polish version of the Light Triad Scale proved to be a valuable and reliable tool which presents an innovative approach to measuring positive features of personality and behaviour. Our results demonstrated that the scale as a whole has good psychometric properties that allow its use in further research.

\section{KEY WORDS}

Polish adaptation; humanism; light triad; faith in humanity; Kantianism

Corresponding Author - Rafał Gerymski, Department of Health Psychology and Quality of Life, Institute of Psychology, Opole University, 1 Staszica Square, 45-052 Opole, Poland, e-mail: rafal.gerymski@uni.opole.pl

AUthors' CONTRIBUtion - A: Study design - B: Data collection · C: Statistical analysis · D: Data interpretation .

E: Manuscript preparation · F: Literature search · G: Funds collection

to Cite this ARTiCle - Gerymski, R., \& Krok, D. (2019). Psychometric properties and validation of the Polish adaptation

of the Light Triad Scale. Current Issues in Personality Psychology, 7(4), 341-354.

RECEIVED 28.11.2019 • REVIEWED 09.12.2019 • ACCEPTED 20.12.2019 • PUBLISHED 30.12.2019 


\section{BACKGROUND}

One of the most influential theories of socially aversive traits in the field of personality and social psychology has been the Dark Triad of personality developed by Paulhus and Williams (2002). Encompassing three dimensions - narcissism, Machiavellianism, and subclinical psychopathy - the Dark Triad has received a lot of empirical attention in psychology with a number of studies devoted to its unique features and correlates related to a wide range of aversive psychosocial outcomes (Dinic \& Wertag, 2018; Koladich \& Atkinson, 2016; Paulhus, 2014). Previous research has demonstrated that individuals who are characterised by high scores on these traits tend to be more arrogant and volatile, and are more likely to engage in antisocial activities and generate social distress.

While this research trend has produced a considerable number of findings enabling us to understand negative aspects of personality, more positive dimensions of mental life and their individual and social consequences have not been much investigated. Meanwhile, the recent literature on positive psychology has revealed a great number of positive characteristics which to a large extent determine human functioning, e.g. life satisfaction, positive emotions, personal growth and self-realization, forgiveness, character strengths (Diener, Suh, Lucas, \& Smith, 1999; Fredrickson, 2001; Peterson \& Seligman, 2004; Ryff \& Keyes, 1995). This approach proved to be academically very productive and successful as it demonstrated that human nature does not only revolve around negativity and pathology, but also reflects a positive, growth-oriented side.

Following the positive psychology path, Kaufman, Yaden, Hyde, and Tsukayama (2019) proposed an alternative construct to the Dark Triad called the Light Triad. Their aim was to counterpose the dark and light side of personality and create a measure encompassing positive personality traits that would be in contrast to dark traits. The idea was not to create a construct that would be a merely reverse-coded version of the Dark Triad (Muris, Merckelbach, Otgaar, \& Meijer, 2017), but to generate a conceptually new orientation to measuring positive aspects of personality. While developing their scale, the main question was: "What would an everyday loving and beneficent orientation toward others look like that is in direct contrast to the everyday antagonistic orientation of those scoring high on dark traits?" (Kaufman et al., 2019 , p. 2). That question ensured the development of a measure reflecting a positive, compassionate, and humanitarian orientation toward others.

Using a large number of different scales measuring Dark Triad dimensions - personality, psychological needs and motives, values and character strengths, defence styles, worldview, self-esteem and authenticity, sex, love, relationships, empathy, compassion, interpersonal styles, selfishness, aggression, moral judgment, religion, spirituality, self-transcendence, curiosity, and life satisfaction - Kaufman et al. (2019) developed the Light Triad Scale (LTS). Across demographically diverse samples, the Light Triad Scale achieved very good reliability and validity. The final version includes three factors: (1) Faith in Humanity it reflects our tendency to believe in the fundamental goodness of people, (2) Humanism - it denotes valuing the dignity and worth of each individual as a unique person, and (3) Kantianism - it consists in relating to people as ends unto themselves and avoiding instrumental treatment. They are independent, though internally consistent constructs that are not additive, i.e. they do not allow us to calculate the total score for the entire scale.

Taken together, the Light Triad Scale reflect an attitude of caring and beneficent orientation toward other people, which is demonstrated in everyday behaviour. Upon examining the conceptual meaning of the three factors, it is quite noticeable that those subscales are deeply rooted in the domain of positive psychology reflecting a generally optimistic view of humans (Lomas \& Ivtzan, 2016; Lopez, Pedrotti, \& Snyder, 2019). Faith in Humanity, Humanism, and Kantianism can be considered as positive-oriented factors which represent the potency of human strengths and underline the tendency of shifting from the negative towards the positive in humans. The emphasis is placed on the realization that people can relate to others in ethically constructive and affirming ways. The Light Triad factors also reflect the human ability to resist, to a large extent, objectionable and egoistic thoughts and desires that incline people to engage in selfish, volatile and ill-disposed ways.

There has not been much research on the Light Triad, as it is a very new construct; to date, the first and only article on the Light Triad was published by Kaufman and colleagues (2019). In it they presented the construct and delineated its conceptual principles. However, having conducted an extensive research project in which an impressive number of 38 scales was used, the authors provided a great wealth of statistical data that enabled them to formulate interesting and valuable conclusions. The results revealed that higher scores on the Light Triad dimensions were related to higher levels of satisfaction with life, empathic and compassionate attitudes, acceptance of other people, conscientiousness, openness to experience, and beliefs that humans are virtuous and good. The Light Triad was also linked to competence, autonomy, secure attachment style, self-esteem, a sense of authenticity, mature defence styles, and many character strengths (e.g. kindness, forgiveness, curiosity, love, perspective, and gratitude). In contrast, there were no significant associations between the Light Triad and assertiveness, bravery, acceptance of external influence and some immature defence styles (i.e. denial and 
displacement). Negative associations were found between the Light Triad dimensions and the motives for achievement and self-enhancement, selfishness, reactive-proactive aggression styles, anxious and avoidant attachment, and self-alienation (Kaufman et al., 2019).

Taken together, these results demonstrated that the Light Triad was associated with more positive and optimistic attitudes, higher levels of personal growth, and greater quality of life and well-being measures. It may imply that vulnerable aspects of aversive personality and negative traits do not constitute 'human nature'; in contrast, people are more likely to perceive and recognise positive personality sides in both themselves and others (Donaldson, Dollwet, \& Rao, 2015; Strohminger, Knobe, \& Newman, 2017). For instance, research demonstrated that psychological well-being which consists of positive traits contributed to people's social and emotional development by helping to understand other people and their social environment, particularly the quality of what is good and worth pursuing (Krok, 2015; Schmid \& Muldoon, 2015). The optimal solution may be the attitude of "golden mean" which focuses on avoiding excess and extremes, whether it be a type of well-being that is so unrealistically sublime, or an overly accentuated search for human inadequacies. People do not seem to perfectly function on a basis of rigid and tight formulae; on the contrary, they rather benefit from a realistic array of both positive and negative characteristics (Shen \& Wyer, 2007). When forming opinions, individuals tend to activate a search process which weighs favourable and unfavourable descriptions that subsequently enable them to evaluate objects, events or situations. Therefore, the Light Triad provides deeper insight into the ways of understanding ethically and socially compassionate, caring beliefs and behaviour.

The prevalence of the positive side of human nature does not invalidate the existence of negative aspects of personality including a bewildering array of strengths and vulnerabilities which play an adaptive role in many life situations. In fact, some authors point out that the "dark" traits are somehow beneficial in positive functioning and adaptation to changing social circumstances (Jonason, Icho, \& Ireland, 2016). The more balanced view encompassing both positive and negative sides of human nature is thus described as the "second wave" of Positive Psychology (Ivtzan, Lomas, Hefferon, \& Worth, 2015). It focuses on finding a compromise between light vs. dark triad scores, which can provide an accurate and objective description of personality.

The aim of this study was to examine whether the Polish version of the Light Triad Scale accurately measures the three-factor construct, like the original American version (Kaufman et al., 2019). For this purpose we evaluated the reliability and validity of the scale in a representative sample of the Polish population. Taking into account cultural differences existing between
Poland and the United States, the use of diagnostic psychological tools requires careful adaptation; because of different cultural contexts, the understanding of particular items as well as reliability and validity coefficients can be different. Based on previous research regarding adaptation of personality scales (Rowiński et al., 2019; Rogoza \& Cieciuch, 2017), we assumed that the Polish version of the Light Triad Scale would encompass the same three factors as the original scale (i.e. Faith in Humanity, Humanism, and Kantianism) and have comparable reliability and validity indices. However, some differences were also expected due to the fact that the measurement of different human characteristics across various populations tends to differ.

\section{METHOD}

\section{PARTICIPANTS AND PROCEDURE}

Four hundred people recruited via the snowball sampling method took part in this study - 134 men and 266 women aged between 18 and $80(M=29.17$ years, $S D=10.60)$. The study participants gave informed consent to participate in the study. The exact characteristics of the study sample can be found in Table 1 .

Table 1

Sociodemographic characteristics of the study sample $(N=400)$

\begin{tabular}{lcc}
\hline & $n$ & $\%$ \\
\hline Gender & 134 & 34.00 \\
$\quad$ Male & 266 & 66.00 \\
$\quad$ Female & & \\
Place of residence & 28 & 7.00 \\
$\quad$ Village & 372 & 93.00 \\
$\quad$ City & & \\
Marital status & 187 & 46.75 \\
$\quad$ Single & 106 & 26.50 \\
$\quad$ Cohabiting & 91 & 22.75 \\
$\quad$ Married & 12 & 3.00 \\
$\quad$ Divorced & 4 & 1.00 \\
$\quad$ Widowed & & \\
Education & 188 & 47.00 \\
Elementary school & 23 & 5.75 \\
Vocational & 14 & 3.50 \\
High school & & \\
$\quad$ University & & \\
\hline
\end{tabular}


All participants were informed that they did not have to answer all of the questions and that they could stop answering them at any given moment. All procedures were performed in accordance with the ethical standards.

\section{MEASURES}

The Light Triad Scale. Three scales were used in this study. The subject of validation was the Light Triad Scale (LTS; Kaufman et al., 2019). This scale contains 12 items divided into 3 subscales: Faith in Humanity, Humanism, and Kantianism. Each subscale consists of 4 items rated on a 5-point scale, ranging from 1 (very strongly disagree) to 5 (very strongly agree). In the original study, the LTS scale showed good reliability (subscales' Cronbach's $\alpha$ was between .67 and .80). The Polish version of the LTS scale was independently translated by 4 people - English native speakers and researchers in the field of health psychology. Based on the collected translations, the final version of the Polish scale has been established (see Appendix 1).

The Polish Dirty Dozen scale. The Polish Dirty Dozen scale (Parszywa Dwunastka) by Czarna, Jonason, Dufner, and Kossowska (2016) was used in order to estimate divergent validity of the LTS. This scale contains 12 items divided into 3 subscales: Machiavellianism, Narcissism and Psychopathy. Each subscale consists of 4 items rated on a 5-point scale, ranging from 1 (very strongly disagree) to 5 (very strongly agree). In the original study, the Dirty Dozen scale showed very good reliability (subscales' Cronbach's $\alpha$ was between .64 and .83). In the present study, this tool was characterized by good reliability (Cronbach's $\alpha=.68$ to .88 ; McDonald's $\omega=.68$ to .86 ).

The International Personality Item Pool-Big Five Aspect Scales. To estimate convergent validity, the agreeableness subscale of the International Personality Item Pool-Big Five Aspect Scales was used (IPIP-BFAS; DeYoung, Quilty, \& Peterson, 2007). The Polish version of the IPIP-BFAS was adapted by Strus, Rowiński, and Cieciuch (2012). The IPIPBFAS agreeableness scale contains 20 items, divided into 3 scores: a summary score and two subscales: compassion (10 items) and kindness (10 items). In the original adaptation (Cronbach's $\alpha=.84$ ) and in the present study (Cronbach's $\alpha=.81$; McDonald's $\omega=.83$ ) agreeableness showed very good reliability.

\section{RESULTS}

\section{DESCRIPTIVE STATISTICS}

Selected descriptive statistics and the Shapiro-Wilk (S-W) test were used in order to examine the characteristics of the variables tested. The S-W test was used due to its high statistical power (Razali \& Wah, 2011). The results showed that distribution of the all tested variables was non-normal. An in-depth analysis of skewness and kurtosis showed that the distributions obtained were not asymmetrical; their values ranged from -2 to 2 (Kim, 2013). The exact results are presented in Table 2. Taking into account the symmetrical distributions, it was decided to use parametric analyses due to their greater power (Francuz \& Mackiewicz, 2005).

We also decided to verify gender differences among the variables examined. For this purpose, the $t$-test was used. The results showed that men obtained significantly higher scores on the scales of Machiavellianism, Psychopathy, and the Dark Triad total score. Conversely, women obtained significantly higher scores on the Faith in Humanity, Humanism, Kantianism, the Light Triad total score, Compassion, Kindness and Agreeableness total score. The results are shown in Table 2.

\section{CONFIRMATORY FACTOR ANALYSIS}

The confirmatory factor analysis (CFA) showed a bad goodness of fit of the one-factor model based on the collected data. The three-factor model was found to be a better fit than the one-factor model, but only the RMSEA coefficient exceeded its limit value. Based on modification indices, error covariances were set within the Humanism subscale items -5 and 6 . This allowed an acceptable 12-item three-factor model to be obtained. Further exploration of the data showed that the two-factor model containing the Faith in Humanity and Humanism subscales was a better fit to the data than the previous three-factor and onefactor models. For detailed information, see Table 3.

Factor loadings analysis for the original threefactor model showed that item 9 had a lower loading than other items from its subscale. Removing this item lowered the goodness of fit indicates, so it was decided to keep that item for further analyses. All other loadings exceeded the .40 value. Table 4 contains standardised factor loadings for the proposed two-factor and three-factor models.

\section{RELIABILITY}

Cronbach's $\alpha$ and McDonald's $\omega$ (Ciżkowicz, 2018) were used to evaluate the internal consistency of the LTS. Measures indicate good reliability of the Faith in Humanity subscale and acceptable reliability of the Humanism subscale. Kantianism was the subscale with the lowest reliability. A more detailed analysis of the data showed that the Kantianism subscale was reliable only after analysing the results of people over the age of 50 . Due to the small size of this sample of 
Rafał Gerymski, Dariusz Krok

Table 2

Descriptive statistics and results of gender comparisons of selected variables $(N=400)$

\begin{tabular}{|c|c|c|c|c|c|c|c|c|c|}
\hline & $M$ & $M E$ & $S D$ & Min & Max & $W$ & $p$ & $S K E$ & $K$ \\
\hline Light Triad & 44.39 & 45.00 & 6.64 & 19.00 & 60.00 & .99 & .008 & -.33 & .28 \\
\hline Faith in Humanity & 13.52 & 14.00 & 3.28 & 4.00 & 20.00 & .97 & $<.001$ & -.44 & -.17 \\
\hline Humanism & 15.04 & 15.00 & 2.81 & 5.00 & 20.00 & .97 & $<.001$ & -.33 & .01 \\
\hline Kantianism & 15.82 & 16.00 & 2.71 & 7.00 & 20.00 & .96 & $<.001$ & -.47 & -.09 \\
\hline Dark Triad & 26.64 & 26.00 & 9.08 & 12.00 & 57.00 & .97 & $<.001$ & .61 & .12 \\
\hline Machiavellianism & 8.11 & 7.00 & 3.78 & 4.00 & 20.00 & .89 & $<.001$ & .92 & .16 \\
\hline Narcissism & 10.28 & 10.00 & 4.01 & 4.00 & 20.00 & .97 & $<.001$ & .17 & -.72 \\
\hline Psychopathy & 8.25 & 8.00 & 3.62 & 3.00 & 20.00 & .91 & $<.001$ & .95 & .46 \\
\hline Agreeableness & 77.57 & 78.00 & 10.02 & 40.00 & 96.00 & .98 & .003 & -.59 & .62 \\
\hline Compassion & 38.82 & 39.00 & 5.41 & 19.00 & 49.00 & .97 & .001 & -.62 & .55 \\
\hline Kindness & 38.75 & 39.00 & 5.74 & 14.00 & 50.00 & .97 & $<.001$ & -.75 & 1.34 \\
\hline \multirow[t]{3}{*}{ Age } & 29.17 & 24.00 & 10.60 & 18.00 & 80.00 & .83 & $<.001$ & 1.42 & 1.66 \\
\hline & \multicolumn{2}{|c|}{ Women } & \multicolumn{2}{|c|}{ Men } & $t_{398}$ & $p$ & LLCI & ULCI & $d_{\text {Cohen }}$ \\
\hline & $M$ & $S D$ & $M$ & $S D$ & & & & & \\
\hline Light Triad & 45.49 & 6.23 & 42.16 & 6.91 & 4.84 & $<.001$ & 1.98 & 4.68 & .51 \\
\hline Faith in Humanity & 13.76 & 3.27 & 13.04 & 3.27 & 2.08 & .038 & .04 & 1.41 & .22 \\
\hline Humanism & 15.55 & 2.60 & 14.02 & 2.94 & 5.31 & $<.001$ & .97 & 2.10 & .55 \\
\hline Kantianism & 16.18 & 2.48 & 15.11 & 3.00 & 3.78 & $<.001$ & .51 & 1.63 & .39 \\
\hline Dark Triad & 25.63 & 8.86 & 28.70 & 9.21 & -3.22 & .001 & -4.95 & -1.19 & .34 \\
\hline Machiavellianism & 7.83 & 3.66 & 8.67 & 3.97 & -2.08 & .038 & -1.62 & -.05 & .22 \\
\hline Narcissism & 10.26 & 4.08 & 10.32 & 3.88 & -.12 & .901 & -.89 & .79 & .01 \\
\hline Psychopathy & 7.53 & 3.35 & 9.71 & 3.72 & -5.90 & $<.001$ & -2.91 & -1.46 & .62 \\
\hline Agreeableness & 79.39 & 9.30 & 71.15 & 9.91 & 4.87 & $<.001$ & 4.90 & 11.58 & .86 \\
\hline Compassion & 39.75 & 5.20 & 35.55 & 4.88 & 4.57 & $<.001$ & 2.39 & 6.02 & .83 \\
\hline Kindness & 39.64 & 5.31 & 35.60 & 6.16 & 4.10 & $<.001$ & 2.09 & 5.98 & .70 \\
\hline
\end{tabular}

Note. W-Shapiro-Wilk's test statistics; SKE - skewness; $K$ - kurtosis.

respondents, it was not possible to perform another confirmatory factor analysis for this group of respondents. Values of the reliability coefficients of the summary scores for two-factor and three-factor models were above .70. For more detailed information see Table 5.

\section{VALIDITY}

The validity of the LTS scale was verified using two methods: the method of content validity and criterion validity. In order to verify the relevance of the LTS, the content validity ratio (CVR; Lawshe, 1975) was used. 10 researchers in the field of health and personality psychology were asked to assess how essential questions selected in factor analysis are to the whole scale. Before assessing the questions, judges were introduced to the concept of the Light Triad. Before evaluating the items, judges were asked to read the original article by Kaufman and colleagues (2019) and were presented with the description of the Light Triad made by the authors of this paper. CVR and CVI (content validity index) measures calculated on the gathered results present positive values. This allowed us to state that all questions were accurate from the theoretical point of view. For more detailed information, see Table 6.

Criterion validity of LTS was measured using Pearson's $r$ correlation coefficient. It was decided to verify 
Table 3

Results of confirmatory factor analysis: goodness of fit measures and internal consistency $(N=400)$

\begin{tabular}{|c|c|c|c|c|c|c|c|c|c|}
\hline & \multirow[t]{2}{*}{$n_{\text {items }}$} & \multirow[t]{2}{*}{$\chi^{2}$} & \multirow[t]{2}{*}{$d f$} & \multirow[t]{2}{*}{$p$} & \multirow[t]{2}{*}{ CFI } & \multirow[t]{2}{*}{ TLI } & \multirow[t]{2}{*}{ RMSEA } & \multicolumn{2}{|c|}{ RMSEA $90 \% \mathrm{Cl}$} \\
\hline & & & & & & & & LLCI & ULCI \\
\hline Model with 1 factor & 12 & 287 & 54 & $<.001$ & .749 & .693 & .104 & .09 & .12 \\
\hline Model with 3 factors & 12 & 146 & 51 & $<.001$ & .897 & .867 & .068 & .06 & .08 \\
\hline $\begin{array}{l}\text { Model with } 3 \text { factors } \\
\& \text { error covariances }\end{array}$ & 12 & 112 & 50 & $<.001$ & .933 & .911 & .056 & .04 & .07 \\
\hline $\begin{array}{l}\text { Model with } 2 \text { factors: } \\
\text { Faith in Humanity } \\
\text { \& Humanism }\end{array}$ & 8 & 62.7 & 19 & $<.001$ & .948 & .909 & .076 & .06 & .10 \\
\hline $\begin{array}{l}\text { Model with } 2 \text { factors } \\
\& \text { error covariances }\end{array}$ & 8 & 33.3 & 18 & .015 & .978 & .966 & .046 & .02 & .07 \\
\hline
\end{tabular}

Table 4

Results of confirmatory factor analysis: factor loadings $(N=400)$

\begin{tabular}{|c|c|c|}
\hline & Items ${ }^{a}$ & $\begin{array}{c}\text { Std. } \\
\text { Estimate }\end{array}$ \\
\hline \multicolumn{3}{|c|}{ Three-Factor Model } \\
\hline \multirow{4}{*}{$\begin{array}{l}\text { Faith in } \\
\text { Humanity }\end{array}$} & 1. I tend to see the best in people & .64 \\
\hline & 2. I tend to trust that other people will deal fairly with me & .69 \\
\hline & 3. I think people are mostly good & .76 \\
\hline & 4. I'm quick to forgive people who have hurt me & .51 \\
\hline \multirow[t]{4}{*}{ Humanism } & 5. I tend to admire others & .46 \\
\hline & 6. I tend to applaud the successes of other people & .62 \\
\hline & 7. I tend to treat others as valuable & .74 \\
\hline & 8. I enjoy listening to people from all walks of life & .50 \\
\hline \multirow[t]{4}{*}{ Kantianism } & 9. I prefer honesty over charm & $.25^{\mathrm{b}}$ \\
\hline & 10. I don't feel comfortable overtly manipulating people to do something I want & 60 \\
\hline & 11. I would like to be authentic even if it may damage my reputation & .45 \\
\hline & 12. When I talk to people, I am rarely thinking about what I want from them & .59 \\
\hline \multicolumn{3}{|c|}{ Two-Factor Model } \\
\hline \multirow{4}{*}{$\begin{array}{l}\text { Faith in } \\
\text { Humanity }\end{array}$} & 1. I tend to see the best in people & .63 \\
\hline & 2. I tend to trust that other people will deal fairly with me & .70 \\
\hline & 3. I think people are mostly good & .77 \\
\hline & 4. I'm quick to forgive people who have hurt me & .50 \\
\hline \multirow[t]{4}{*}{ Humanism } & 5. I tend to admire others & .49 \\
\hline & 6. I tend to applaud the successes of other people & .63 \\
\hline & 7. I tend to treat others as valuable & .71 \\
\hline & 8. I enjoy listening to people from all walks of life & .49 \\
\hline
\end{tabular}

Note. ${ }^{a}$ items in Polish can be found in Appendix $1 ;{ }^{\mathrm{b}}$ removal of this item lowered the goodness of fit indicates 
Table 5

Results of reliability analysis for 12 items: internal consistency $(N=400)$

\begin{tabular}{llcc}
\hline & & Cronbach's $\alpha$ & McDonald's $\omega$ \\
\hline Subscales & Faith in Humanity & .73 & .75 \\
& Humanism & .65 & .67 \\
Summary score & Kantianism & .54 & .54 \\
& Three-Factor Model & .73 & .75 \\
& Two-Factor Model* & .76 & .77 \\
\hline
\end{tabular}

Note. ${ }^{*}$ Faith in Humanity \& Humanism

Table 6

Results of validity analysis: CVR and CVI measures $(N=400)$

\begin{tabular}{|c|c|c|c|}
\hline Factor & Items ${ }^{\mathrm{a}}$ & CVR & $\mathrm{CVI}$ \\
\hline \multirow{4}{*}{$\begin{array}{l}\text { Faith in } \\
\text { Humanity }\end{array}$} & 1. I tend to see the best in people & .80 & \\
\hline & 2. I tend to trust that other people will deal fairly with me & .99 & \\
\hline & 3. I think people are mostly good & .99 & \\
\hline & 4. I'm quick to forgive people who have hurt me & .80 & \\
\hline \multirow[t]{4}{*}{ Humanism } & 5. I tend to admire others & .60 & \\
\hline & 6. I tend to applaud the successes of other people & .40 & \\
\hline & 7. I tend to treat others as valuable & .99 & .68 \\
\hline & 8. I enjoy listening to people from all walks of life & .80 & \\
\hline \multirow[t]{4}{*}{ Kantianism } & 9. I prefer honesty over charm & .20 & \\
\hline & $\begin{array}{l}\text { 10. I don't feel comfortable overtly manipulating people to do something } \\
\text { I want }\end{array}$ & .60 & \\
\hline & 11. I would like to be authentic even if it may damage my reputation & .20 & \\
\hline & 12. When I talk to people, I am rarely thinking about what I want from them & .80 & \\
\hline
\end{tabular}

Note. ${ }^{\mathrm{a}}$ items in Polish can be found in Appendix 1

the relationship between the Light Triad Scale, two other theoretically related scales - Parszywa Dwunastka and the IPIP-BFAS agreeableness subscale, and age. All three LTS subscales and summary scores were significantly and positively related to the agreeableness scores. Kantianism was significantly and negatively related to all Dark Triad traits. Humanism and Faith in Humanity subscales were not significantly related to the narcissism subscale. Most significant correlations were moderate. There was also a positive significant relationship between Kantianism and age. For more detailed information see Table 7.

\section{DISCUSSION}

The aim of this article was to validate the Polish version of the Light Triad Scale (LTS; Kaufman et al.,
2019). For this purpose, confirmatory factor analysis, reliability analysis using $\alpha$ and $\omega$ coefficients, and two measures of validity (content and criterion validity) were used on a sample of 400 participants. The results indicate that the Polish version of the scale has good psychometric properties, though it still requires further efforts. The statistical analyses confirmed an acceptable fit of the three-factor model. The two-factor model not containing the Kantianism subscale had a better fit to the data than the original three-factor model. This may be due to the low reliability of the Kantianism construct. It indicates that the scale can be used as both two-factor and threefactor constructs. Although the two-factor model fits better to the empirical data, the difference between the two models is rather small, which justifies using both models. The main reason why the Kantianism subscale showed low reliability may come 
Light Triad Scale

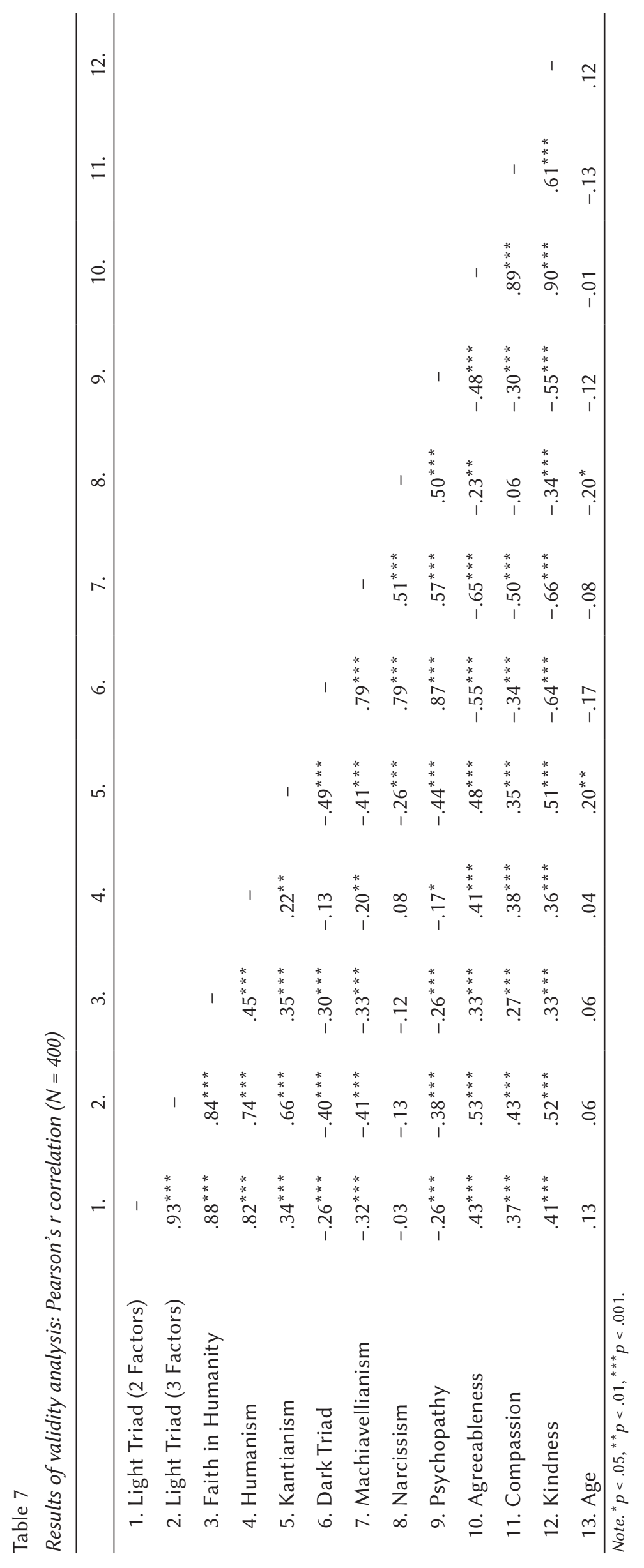


from the specificity of its items, which could have been differently understood in the Polish population than the American one. Some of the items included in Kantianism, e.g. "I prefer honesty over charm" or "I would like to be authentic even if it may damage my reputation", could be interpreted by the Polish respondents in equivocal ways, i.e. either as treating people as an end, not as a means to an end (the emphasis is on the interpersonal aspect), or as being honest and faithful to oneself (the emphasis in on the intrapersonal aspect). As a consequence, this difference which frequently plays a role in crosscultural adaptation of questionnaires (Epstein, Santo, \& Guillemin, 2015) may have affected the Polish version.

The highest $\alpha$ and $\omega$ coefficients, exceeding the .70 value, were obtained in the Faith in Humanity subscale. Humanism had those values at an acceptable level above .60. Kantianism had acceptable reliability only in a group of people over 50 years old. This finding may reflect the prosocial nature of this subscale and its connections to pro-social values as these qualities mainly characterise the older population (Brožek, 1955; Edwards \& Wine, 1963; Soto, John, Gosling, \& Potter, 2011; Srivastava, John, Gosling, \& Potter, 2003). Having acquired a broader, more experienced perspective of their life, older people tend to be better predisposed to show concerns and empathy for the rights, feelings, and wellbeing of others. The relationship between Kantianism and age observed in this paper seems to confirm these assumptions. Despite the fact that Kantianism had acceptable internal consistency indices mainly in the 50+ year-old group, other psychometric properties (CVR and CVI measures, Pearson's $r$ correlation with the Dark Triad and Agreeableness) suggest that it can be used with some caution in other age groups.

The validity measure using CVR and CVI indicated that the scale items fit well into the concept of the Light Triad. Pearson's $r$ correlation specified that the Light Triad Scale is moderately related to the agreeableness scores, which indicated its validity. The correlations between the Light Triad Scale and Agreeableness are substantially lower in the current paper than the original one. The Polish version had comparable indices of validity, despite the fact that the correlations between the Light Triad Scale and Agreeableness were substantially lower in the current study than the original one. It confirms the fact that the Light Triad is not a redundant measure of Big Five Agreeableness.

In their original article Kaufman and colleagues (2019) stated that the Light Triad was not in direct opposition to the Dark Triad concept. The weak and moderate correlations between Dark Triad and Light Triad traits obtained in our study are similar to those in the original validation. In the current study, Faith in Humanity and Humanism were not statistically related to Narcissism. The authors of the original validation reported the relationship between Narcissism and Faith in Humanity and Humanism as significant, but the correlation coefficient value was very small, i.e. only .07 . There is a possibility that this might be either an error or statistical artefact due to the original adaptation's large sample size $(N=1518)$. In addition, the insignificance of this relationship can also be justified from a theoretical point of view. Narcissism contains positive (e.g. striving for uniqueness, charming behaviour) and negative (e.g. aggressive behaviour, devaluation of others) components (Back et al., 2013). Since those two spheres are positively related (Rogoza \& Cieciuch, 2018; Rogoza, Wyszyńska, Maćkiewicz, \& Cieciuch, 2016), they might balance the relationship between narcissism and the Light Triad subscales. Carter and colleagues (2015) claimed that the Dark Triad construct properties could vary among different groups. According to them, the Dark Triad should be considered a one-factor construct in non-student samples. Furthermore, its properties tend to vary depending on the age group, so using this construct in such a broad sample as the one in our research (aged between 18 and 80 years old) would not be desired. This finding appears rather interesting as it suggests verification of the relationship between "Light" and "Dark" traits once again. Perhaps, using tools such as MACH-IV (Panitz, 1989), TriPM (Evans \& Tully, 2016) and NPI-16 (Ames, Rose, \& Anderson, 2006) would give different results.

Another point which requires interpretation is the ninth item of the scale (I prefer honesty over charm), which has a moderate fit index within the Kantianism subscale. Its factor loading did not exceed the threshold .40 value, but removing it lowered the goodness of fit indices and did not change the subscales' reliability. In the content validity analysis, this item obtained the lowest score $(\mathrm{CVR}=.20)$. The Light Triad translators also discussed this question. It was translated as Cenię bardziej uczciwość niż wdzięk or Cenię bardziej uczciwość niż wygląd and Cenię bardziej uczciwość niż urok. Determining the most appropriate version of this item was done arbitrarily by the authors of the current adaptation. Based on the tone of the item we do not know with absolute certainty whether this item asks about honesty and charm in oneself or other people. It is especially evident in the context of the other subscale items, which clearly relate to other people. This question should be given special attention in the case of further scale validation. We are currently planning a further validation process which will take into account a modified version of the ninth item. Alternatively, it is possible to apply the Kantianism subscale without the ninth item when examining the general population. 
The novelty of the Light Triad scale is undoubtedly a very beneficial aspect of our research. Although there has not yet been much data presenting psychometric properties of the Light Triad scale due to its recent publication (Kaufman et al., 2019), the authors of the original version carried out broad research which compared the Light Triad with the results of a remarkable number of other psychological tools (in sum 38 different scales) measuring various aspects of individual and social characteristics. Our research has confirmed the legitimacy of this research trend to examine a conceptually new orientation to measuring positive aspects of personality. It taps into a broad area of contemporary positive psychology that attempts to emphasize the importance of affirmative and positive characteristics related to life satisfaction, human development, and personal growth in conjunction with accepting the existence, and even adaptive usefulness, of negative traits (Greven, Buitelaar, \& Salum, 2018; Ivtzan et al., 2015). Such dimensions as Kantianism, Humanism, and Faith in Humanity enrich our understanding of human behaviour and shed new light on the ways in which individuals try to achieve important goals, relate to others and complete their tasks.

Although our study produced a new and interesting scale, it is not free of limitations. Despite the fact that the tested sample meets the requirements of psychometric validation (at least $N=10$ per item) and CFA (at least $N=200$ ), it is not fully representative. 400 people are only a small part of the Polish population. In addition, the trial did not include a clinical sample, so it is difficult to predict how the current scale could work in groups of clinical patients. Moreover, the reliability of the Kantianism subscale does not allow its use on the general population; at least the authors of the Polish adaptation do not recommend it. A thorough analysis of reliability showed that this subscale is reliable only for people over 50 years of age. Consequently, a new psychometric analysis should be carried out on a representative group of older adults and the elderly.

Despite these limitations, our results stress the importance of the validation work conducted on the Light Triad concept. Overall, the Polish version of the Light Triad Scale proved to be a valuable and reliable tool, which presents an innovative approach to measuring positive features of personality and behaviour. Our results demonstrated that the scale as a whole has good psychometric properties that allow its use in further research. Given the growing interest in measuring positive aspects of human life, the findings obtained in the current study offer valuable guidance for personality and health psychology professionals. The scale thus seems highly promising as it provides new empirical evidence to investigate the light side of personality.

\section{RefERENCES}

Ames, D. R., Rose, P., \& Anderson, C. P. (2006). The NPI-16 as a short measure of narcissism. Journal of Research in Personality, 40, 440-450. https://doi. org/10.1016/j.jrp.2005.03.002

Back, M. D., Küfner, A. C., Dufner, M., Gerlach, T. M., Rauthmann, J. F., \& Denissen, J. J. (2013). Narcissistic admiration and rivalry: Disentangling the bright and dark sides of narcissism. Journal of Personality and Social Psychology, 105, 1013-1037. https://doi.org/10.1037/a0034431

Brožek, J. (1955). Personality changes with age: an item analysis of the Minnesota Multiphasic Personality Inventory. Journal of Gerontology, 10, 194-206. https://doi.org/10.1093/geronj/10.2.194

Carter, G. L., Campbell, A. C., Muncer, S., \& Carter, K. A. (2015). A Mokken analysis of the Dark Triad 'Dirty Dozen': Sex and age differences in scale structures, and issues with individual items. Personality and Individual Differences, 83, 185-191. https://doi.org/10.1016/j.paid.2015.04.012

Ciżkowicz, B. (2018). Omega McDonalda jako alternatywa dla alfa Cronbacha w szacowaniu rzetelności testu [McDonald's omega as an alternative to Cronbach's alpha in scale score reliability estimation]. Polskie Forum Psychologiczne, 23, 311-329.

Czarna, A. Z., Jonason, P. K., Dufner, M., \& Kossowska, M. (2016). The Dirty Dozen Scale: Validation of a Polish version and extension of the nomological net. Frontiers in Psychology, 7, 1-12. https://doi. org/10.3389/fpsyg.2016.00445

DeYoung, C. G., Quilty, L. C., \& Peterson, J. B. (2007). Between facets and domains: 10 aspects of the Big Five. Journal of Personality and Social Psychology, 93, 880-896. https://doi.org/10.1037/00223514.93.5.880

Diener, E., Suh, E. M., Lucas, R. E., \& Smith, H. L. (1999). Subjective well-being: Three decades of progress. Psychological Bulletin, 125, 276-302. https://doi. org/10.1037/0033-2909.125.2.276

Dinic, B., \& Wertag, A. (2018). Effects of dark triad and HEXACO traits on reactive/proactive aggression: Exploring the gender differences. Personality and Individual Differences, 123, 44-49. https://doi. org/10.1016/j.paid.2017.11.003

Donaldson, S. I., Dollwet, M., \& Rao, M. A. (2015). Happiness, excellence, and optimal human functioning revisited: Examining the peer-reviewed literature linked to positive psychology. The Journal of Positive Psychology, 10, 185-195. https://doi. org/10.1080/17439760.2014.943801

Edwards, A. E., \& Wine, D. B. (1963). Personality changes with age; their dependency on concomitant intellectual decline. Journal of Gerontology, 18, 182-184. https://doi.org/10.1093/geronj/18.2.182

Epstein, J., Santo, R. M., \& Guillemin, F. (2015). A review of guidelines for cross-cultural adaptation 
of questionnaires could not bring out a consensus. Journal of Clinical Epidemiology, 68, 435-441. https://doi.org/10.1016/j.jclinepi.2014.11.021

Evans, L., \& Tully, R. J. (2016). The triarchic psychopathy measure (TriPM): Alternative to the PCL-R? Aggression and Violent Behavior, 27, 79-86. https:// doi.org/10.1016/j.avb.2016.03.004

Francuz, P., \& Mackiewicz, R. (2005). Liczby nie wiedza, skąd pochodza [The numbers don't know where they came from]. Lublin: Wydawnictwo KUL.

Fredrickson, B. L. (2001). The role of positive emotions in positive psychology: The broaden- and-build theory of positive emotions. American Psychologist, 56, 218-226. https://doi.org/10.1037//0003066x.56.3.218

Greven, C. U., Buitelaar, J. K., \& Salum, G. A. (2018). From positive psychology to psychopathology: The continuum of attention-deficit hyperactivity disorder. Journal of Child Psychology and Psychiatry, 59, 203-212. https://doi.org/10.1111/jcpp.12786

Ivtzan, I., Lomas, T., Hefferon, K., \& Worth, P. (2015). Second wave positive psychology: Embracing the dark side of life. London: Routledge.

Jonason, P. K., Icho, A., \& Ireland, K. (2016). Resources, harshness, and unpredictability: the socioeconomic conditions associated with the Dark Triad traits. Evolutionary Psychology, 14, 1-11. https:// doi.org/10.1177/1474704915623699

Kaufman, S. B., Yaden, D. B., Hyde, E., \& Tsukayama, E. (2019). The Light vs. Dark Triad of Personality: Contrasting two very different profiles of human nature. Frontiers in Psychology, 10, 467. https://doi.org/10.3389/fpsyg.2019.00467

Kim, H. Y. (2013). Statistical notes for clinical researchers: assessing normal distribution (2) using skewness and kurtosis. Restorative Dentistry and Endodontics, 38, 52-54. https://doi.org/10.5395/rde.2013. 38.1 .52

Koladich, S. J., \& Atkinson, B. E. (2016). The dark triad and relationship preferences: a replication and extension. Personality and Individual Differences, 94, 253-255. https://doi.org/10.1016/j.paid.2016.01.023

Krok, D. (2015). The mediating role of optimism in the relations between sense of coherence, subjective and psychological well-being among late adolescents. Personality and Individual Differences, 85, 134-139. https://doi.org/10.1016/j.paid.2015.05.006

Lawshe, C. H. (1975). A quantitative approach to content validity. Personnel Psychology, 28, 563-575. https://doi.org/10.1111/j.1744-6570.1975.tb01393.x

Lomas, T., \& Ivtzan, I. (2016). Second wave positive psychology: Exploring the positive-negative dialectics of wellbeing. Journal of Happiness Studies, 17, 17531768. https://doi.org/10.1007/s10902-015-9668-y

Lopez, S. J., Pedrotti, J. T., \& Snyder, C. R. (2019). Positive psychology: The scientific and practical explorations of human strengths. Los Angeles, CA: Sage Publications.
Muris, P., Merckelbach, H., Otgaar, H., \& Meijer, E. (2017). The malevolent side of human nature: a meta-analysis and critical review of the literature on the Dark Triad (narcissism, Machiavellianism, and psychopathy). Perspectives in Psychological Science, 12, 183-204. https://doi.org/10.1177/ 1745691616666070

Panitz, E. (1989). Psychometric investigation of the Mach IV scale measuring Machiavellianism. Psychological Reports, 64, 963-968. https://doi. org/10.2466/pr0.1989.64.3.963

Paulhus, D. L. (2014). Toward a taxonomy of dark personalities. Current Directions in Psychological Science, 23, 421-426. https://doi.org/10.1177/096372 1414547737

Paulhus, D. L., \& Williams, K. M. (2002). The Dark Triad of personality: Narcissism, Machiavellianism, and psychopathy. Journal of Research in Personality, 36, 556-563. https://doi.org/10.1016/S00926566(02)00505-6

Peterson, C., \& Seligman, M. E. P. (2004). Character strengths and virtues: A classification and handbook. Washington, DC: American Psychological Association.

Razali, N. M., \& Wah, Y. B. (2011). Power comparisons of Shapiro-Wilk, Kolmogorov-Smirnov, Lilliefors and Anderson-Darling tests. Journal of Statistical Modeling and Analytics, 2, 21-33.

Rogoza, R., \& Cieciuch, J. (2017). Structural investigation of the Short Dark Triad questionnaire in Polish population. Current Psychology, 38, 756-763. https://doi.org/10.1007/s12144-017-9653-1

Rogoza, R., \& Cieciuch, J. (2018). Dark Triad traits and their structure: an empirical approach. Current Psychology. https://doi.org/10.1007/s12144-018-9834-6

Rogoza, R., Wyszyńska, P., Maćkiewicz, M., \& Cieciuch, J. (2016). Differentiation of the two narcissistic faces in their relations to personality traits and basic values. Personality and Individual Differences, 95, 85-88. https://doi.org/10.1016/j.paid.2016.02.038

Rowiński, T., Kowalska-Dąbrowska, M., Strus, W., Cieciuch, J., Czuma, I., Żechowski, C., Markon, K. E., \& Krueger, R. F. (2019). Measurement of pathological personality traits according to the DSM-5: a Polish adaptation of the PID-5. Part II-empirical results. Psychiatria Polska, 53, 23-48. https://doi. org/10.12740/PP/OnlineFirst/86478

Ryff, C. D., \& Keyes, C. L. M. (1995). The structure of psychological well-being revisited. Journal of Personality and Social Psychology, 69, 719-727. https://doi.org/10.1037/0022-3514.69.4.719

Schmid, K., \& Muldoon, O. T. (2015). Perceived threat, social identification, and psychological well-being: The effects of political conflict exposure. Political Psychology, 36, 75-92. https://doi.org/10.1111/ pops. 12073

Shen, H., \& Wyer Jr, R. S. (2007). Procedural priming and consumer judgments: Effects on the impact 
of positively and negatively valenced information. Journal of Consumer Research, 34, 727-737. https:// doi.org/10.1086/523292

Soto, C. J., John, O. P., Gosling, S. D., \& Potter, J. (2011). Age differences in personality traits from 10 to 65: Big Five domains and facets in a large crosssectional sample. Journal of Personality and Social Psychology, 100, 330-348. https://doi.org/10.1037/ a0021717

Srivastava, S., John, O. P., Gosling, S. D., \& Potter, J. (2003). Development of personality in early and middle adulthood: Set like plaster or persistent change? Journal of Personality and Social Psychology, 84, 1041-1053. https://doi.org/10.1037/00223514.84.5.1041

Strohminger, N., Knobe, J., \& Newman, G. (2017). The true self: a psychological concept distinct from the self. Perspectives in Psychological Science, 12, 551560. https://doi.org/10.1177/1745691616689495

Strus, W., Rowiński, T., \& Cieciuch, J. (2012). Polish version of Bigfive Aspects Scales from International Personality Item Pool. Triest: 16th European Conference on Personality. 
1. I tend to see the best in people.

2. I tend to trust that other people will deal fairly with me.

3. I think people are mostly good.

4. I'm quick to forgive people who have hurt me.

5. I tend to admire others.

6. I tend to applaud the successes of other people.

7. I tend to treat others as valuable.

8. I enjoy listening to people from all walks of life.

9. I prefer honesty over charm.

10. I don't feel comfortable overtly manipulating people to do something I want.

11. I would like to be authentic even if it may damage my reputation.

12. When I talk to people, I am rarely thinking about what I want from them.
1. Zazwyczaj widzę w ludziach to, co najlepsze.

2. Zwykle ufam, że inni ludzie będą ze mną postępować uczciwie.

3. Myślę, że ludzie są na ogół dobrzy.

4. Szybko wybaczam ludziom, którzy mnie skrzywdzili.

5. Mam tendencję do podziwiania innych.

6. Mam skłonność, aby chwalić sukcesy innych ludzi.

7. Staram się traktować innych ludzi jako wartościowych.

8. Lubię słuchać ludzi ze wszystkich środowisk.

9. Cenię bardziej uczciwość niż wdzięk.

10. Źle się czuję, manipulując ludźmi dla własnej korzyści.

11. Chciałbym pozostać sobą, nawet jeśli miałoby mi to zaszkodzić.

12. W rozmowie z ludźmi rzadko dążę do zaspokojenia własnych korzyści. 
APPENDIX 2

SKALA JASNEJ TRIADY - LIGHT TRIAD SCALE

(ADAPTACJA: GERYMSKI \& KROK, 2019)

Wskaż, proszę, na ile zgadzasz się z każdym z poniższych stwierdzeń w oparciu o następującą skalę: 1 - Zdecydowanie się nie zgadzam

2 - Nie zgadzam się

3 - Nie mam zdania

4 - Zgadzam się

5 - Zdecydowanie się zgadzam

$\begin{array}{lllll}1 & 2 & 3 & 4 & 5\end{array}$

1. Zazwyczaj widzę w ludziach to, co najlepsze.

2. Zwykle ufam, że inni ludzie będą ze mną postępować uczciwie.

3. Myślę, że ludzie są na ogół dobrzy.

4. Szybko wybaczam ludziom, którzy mnie skrzywdzili.

5. Mam tendencję do podziwiania innych.

6. Mam skłonność, aby chwalić sukcesy innych ludzi.

7. Staram się traktować innych ludzi jako wartościowych.

8. Lubię słuchać ludzi ze wszystkich środowisk.

9. Cenię bardziej uczciwość niż wdzięk.

10. Źle się czuję, manipulując ludźmi dla własnej korzyści.

11. Chciałbym pozostać sobą, nawet jeśli miałoby mi to zaszkodzić.

12. W rozmowie z ludźmi rzadko dążę do zaspokojenia własnych korzyści.

Faith in Humanity / Wiara w ludzi: 1, 2, 3, 4.

Humanism / Humanizm: 5, 6, 7, 8.

Kantianism / Kantyzm: 9, 10, 11, 12. 